\title{
REVIEW
}

\section{PENGELOLAAN DAN KONSERVASI SATWA BERBASIS KEARIFAN TRADISIONAL DI PAPUA \\ (Wildlife Management and Conservation Based on Traditional Wisdom in Papua)}

\author{
Freddy Pattiselanno $^{1 *}$, Jacob Manusawai ${ }^{2}$, Agustina Y.S. Arobaya ${ }^{3}$ \\ dan Herman Manusawai ${ }^{3}$ \\ ${ }^{1}$ Laboratorium Produksi Ternak, Fakultas Peternakan Perikanan dan Ilmu Kelautan, \\ Universitas Papua, Jl. Gunung Salju Amban Manokwari 98314 Papua Barat. \\ ${ }^{2}$ Program Studi Manajemen Hutan, Fakultas Kehutanan, Universitas Papua, \\ Jl. Gunung Salju Amban Manokwari 98314 Papua Barat. \\ ${ }^{3}$ Laboratorium Lingkungan dan Konservasi Hutan, Fakultas Kehutanan, \\ Universitas Papua, Jl. Gunung Salju Amban Manokwari 98314 Papua Barat. \\ *Penulis Korespondensi. No Telp. 0986-212156; Fax. 0986-211455. \\ Email: pattiselannofreddy@yahoo.com.
}

Diterima: 29 Juni 2014

Disetujui: 19 November 2014

\begin{abstract}
Abstrak
Kearifan tradisional didefinisikan sebagai sistem sosial, politik, budaya, ekonomi dan lingkungan dalam kehidupan suatu komunitas tertentu yang dinamis, berkelanjutan dan dapat diterima. Artikel ini bertujuan untuk mendiskusikan konsep kearifan tradisional dalam akitivitas perburuan satwa pada kelompok etnik tertentu di Papua sebagai langkah alternatif konservasi satwa. Hasil penelitian menunjukkan bahwa aspek kearifan tradisional oleh masyarakat asli Papua bervariasi antara satu dengan lainnya. Konsep-konsep yang berhasil diidentifikasi dan masih tetap dipraktekkan sampai dengan saat ini di antaranya teknik dan peralatan berburu, lokasi perburuan, musim berburu dan target perburuan. Kesemuanya adalah potensi yang harus dilestarikan dan dikembangkan guna menunjang program konservasi satwa di Papua.
\end{abstract}

Kata kunci: kearifan tradisional, konservasi, Papua, perburuan, satwa.

\begin{abstract}
Traditional wisdom is defined as social, politic, culture, economics and environment system in particular communities life which dynamic, sustainably and acceptable. This article aimed to discuss traditional wisdom concept in wildlife hunting by some ethnic groups in Papua as an alternative way on wildlife conservation. The study indicated that traditional wisdom aspect of the native Papuan was varies among others. An identified concept of traditional wisdom which still put into practice around the study site was technique and tools of hunting, location, hunting season and hunting target. This concept is the potency which could be sustained and developed in order to support the wildlife conservation program in Papua.
\end{abstract}

Keywords: conservation, hunting, Papua, traditional wisdom, wildlife.

\section{PENDAHULUAN}

Perburuan didefinisikan sebagai alat untuk memanen satwa. Dalam kenyataannya, pemanfaatan satwa di Papua murni dilakukan melalui aktivitas perburuan. Berburu dan mengumpulkan hewan liar telah berlangsung sejak dahulu dan merupakan aspek penting dalam kehidupan masyarakat di pedalaman Papua. Oleh karena itu sekalipun dalam kehidupan modern sekarang ini beberapa kelompok etnik di Papua sangat bergantung pada aktivitas perburuan sebagai bagian dari tradisi mereka (Pattiselanno, 2003). Dengan kata lain, perburuan merupakan satu di antara beberapa cara hidup masyarakat asli Papua.
Sejalan dengan perkembangan waktu, saat ini tujuan utama dari aktivitas perburuan yaitu untuk memenuhi kebutuhan protein hewani utama masyarakat sebagai sumber pangan, dan mendapatkan keuntungan ekonomis dengan menjual hewan hidup dan produk yang dihasilkannya (daging, kulit, tanduk, telur, taring, ekor dan lain sebagainya). Walaupun demikian, secara umum perburuan satwa di Papua bersifat subsistens dengan fokus utama untuk menyiapkan sumber protein esensial yaitu daging untuk kebutuhan konsumsi keluarga (Pattiselanno, 2003).

Kearifan tradisional adalah sistem sosial, politik, budaya, eknomi dan lingkungan dalam kehidupan suatu komunitas lokal yang bersifat dinamis, berkelanjuan dan dapat diterima. Dalam 
kehidupan masyarakat, kearifan tradisional merupakan bagian dari sistem hukum, pengetahuan, keahlian, nilai, etika dan sosial yang hidup dan berkembang dari satu generasi ke generasi berkutnya. Tabu yang berkaitan dengan kepercayaan atau praktek budaya dianggap sebagai kearifan tradisional diantara kelompok etnik (Madhusudan dan Karanth, 2002). Dalam hubungannya dengan aktivitas perburuan satwa, tabu yang bersifat sosial secara tradisional merupakan pelindung terhadap praktek pemanfaatan spesies satwa tertentu yang tidak terkontrol (Hill dan Padwe, 2000; Leuwenberg dan Robinson, 2000). Tabu seperti ini dapat menyebar di beberapa wilayah, atau terbatas pada kelompok etnik tertentu, klan ataupun keluarga (Bennett dan Robinson, 2000).

Tulisan ini bertujuan untuk mendiskusikan konsep kearifan tradisional yang berlaku dalam kegiatan perburuan satwa oleh beberapa kelompok etnik di Papua sebagai alternatif pelestarian satwa. Berdasarkan hasil pengamatan dan tinjauan literatur terhadap aspek-aspek yang merupakan bagian dari praktek kearifan tradisional masyarakat setempat, maka diharapkan informasi ini dapat mengungkap konsep tradisional yang mendukung usaha konservasi satwa di wilayah itu.

\section{TEKNIK DAN PERALATAN BERBURU}

Aktivitas perburuan di Papua umumnya merupakan perburuan subsistens yang sangat bergantung pada alat buru tradisional dalam hubungannya dengan menjaga hubungan antara manusia dengan alam. Beberapa literatur (Bennett dan Robinson, 2000; Milner-Gulland dan Bennett, 2003) menyatakan bahwa perburuan subsistens umumnya menggunakan alat buru tradisional yang sederhana dengan tujuan utama menyediakan sumber protein esensial untuk kebutuhan konsumsi keluarga. Pemburu mengadopsi penggunaan produk hutan seperti kayu, bambu dan rotan untuk membuat jerat, mendesain perangkap, membuat panah, busur dan tombak. Tumbuhan hutan yang elastis dan mudah untuk dibentuk, dilengkungkan serta tumbuhan penghasil serat tumbuhan diambil dan dianyam sebagai pengganti tali.

Berburu biasanya dilakukan secara perorangan maupun kelompok. Perburuan dalam kelompok besar biasanya terdiri dari banyak orang dengan bantuan anjing pemburu dan dilakukan pada waktuwaktu tertentu misalnya untuk kegiatan pesta adat, budaya ataupun perayaan hari-hari besar keagamaan. Untuk perburuan individu biasanya dilakukan oleh pasangan suami isteri pada saat mereka bekerja di kebun. Pemeriksaan perangkap secara rutin biasanya dilakukan secara individu pada saat yang sama pekerjaan di kebun dilakukan.

Paijmans (1976), Chahya (2000), dan Pattiselanno (2005) menjelaskan bahwa bahan pembuat peralatan berburu umumnya diambil dari alam termasuk berbagai jenis kayu, bambu, liana dan dan serat tumbuhan. Menurut Paijmans (1976) material untuk peralatan berburu biasanya diambil dari hutan seperti Hibiscus sp., Trema sp., Ficus spp, Syzigium sp., Aglaia sapindina dan Dodonea viscose. Beberapa kelompok etnik tertentu menggunakan anjing dan api untuk mengusir dan menghalau hewan buruan (Manembu, 1991; Flannery, 1995).

Lee (2000) menjelaskan bahwa perburuan secara luas dapat dibagi menjadi perburuan aktif dimana pemburu secara aktif mencari hewan buruan, memerlukan waktu dan tenaga yang intensif. Di sisi lain, perburuan pasif membutuhan usaha awal seperti mendesain perangkap, memasang jerat, oleh karena itu Pattiselanno (2005) menjelaskan bahwa di Papua teknik perburuan aktif dan pasif dalam aktivitas perburuan satwa (Gambar 1 dan 2).

\section{LOKASI PERBURUAN}

Hal yang umum hampir di sebagian besar daerah di Papua, penduduk desa tidak sangsi lagi bahwa di sekitar hutan terdapat daerah sakral dan penduduk/pemburu tidak diperkenankan melakukan aktivitas berburu di daerah tersebut. Praktek ini dilakukan secara turun temurun dan sampai saat ini tetap dilakukan.

Kepercayaan yang tetap berlangsung yaitu tempat tertentu harus dilindungi dan tidak dapat diganggu karena tempat tersebut digunakan sebagai tempat berdiamnya roh/arwah nenek moyang mereka. Tempat yang paling sering dilindungi antara lain daerah aliran sungai, daerah perbukitan tertentu dan tempat-tempat yang didominasi oleh pepohonan yang besar. Masing-masing kelompok etnik mempunyai karakteristik tempat sakral yang berbeda. Fenomena yang sama juga berlaku di India dan menurut Madhusudan and Karanth (2002) hutan sakral sangat terbatas pengunaannya dan dilarang melakukan aktivitas perburuan di wilayah tersebut.

Selain itu juga, lokasi berburu biasanya terbatas pada tiap wilayah klen atau berdasarkan hak ulayat yang jelas dari kelompok etnik atau marga tertentu. Batas-batas ulayat secara tradisional diatur menurut pertemuan adat antar kelompok atau klen tertentu dan disepekati serta dihargai secara turun temurun. Batas tersebut biasanya ditandai 


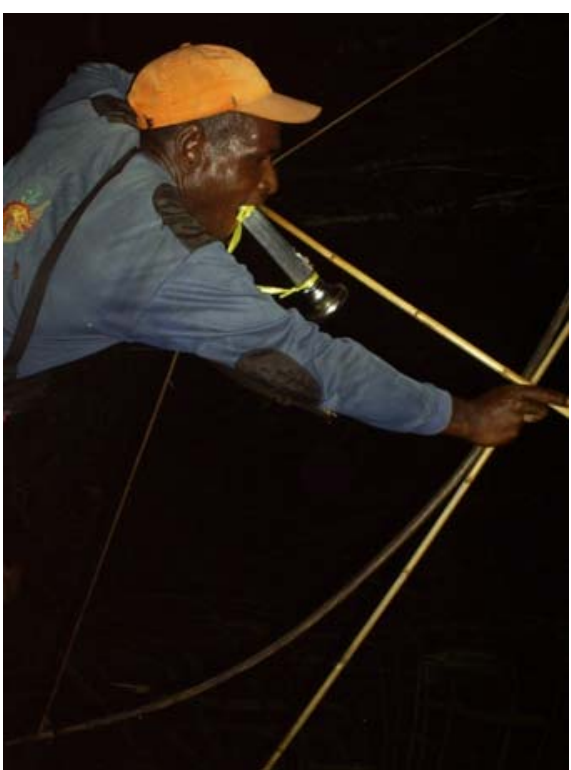

Gambar 1. Perburuan aktif dengan menggunakan busur dan panah.

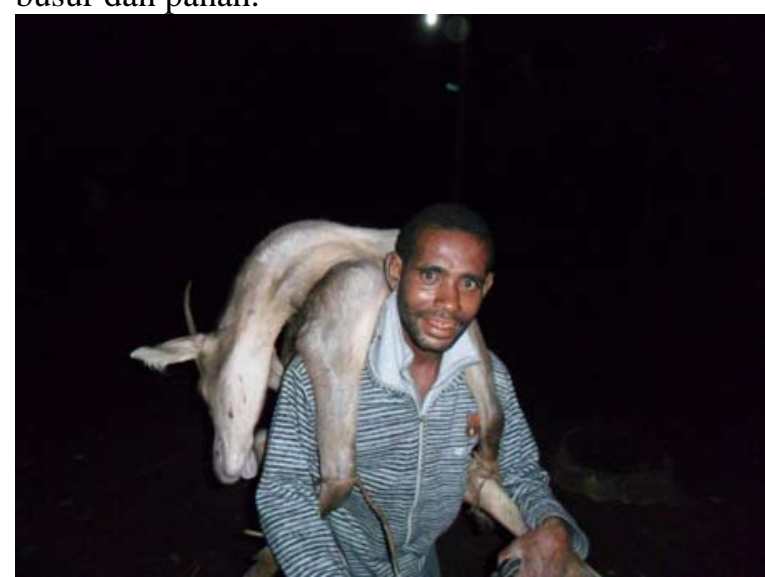

Gambar 3. Pemburu di Amberbaken membawa rusa hasil buruan.

berdasarkan bentang alam seperti gunung atau sungai yang menggambarkan marga tertentu. Oleh karena itu masyarakat pemilik ulayat memiliki wewenang untuk melarang dan mengijinkan mereka yang bukan pemilik ulayat memanfaatkan lahannya. Misalnya seorang yang bukan berasal dari kelompok atau klen pemilik lahan ulayat tidak diperkenankan berburu di lokasi yang bukan merupakan hak ulayatnya.

Batas - batas tersebut secara tegas dan sadar dipahami oleh masyarakat anggota klen tersebut sehingga dalam melakukan kegiatan berburu mereka tidak boleh melintas atau melewati batasbatas hak ulayat mereka. Menurut Wanggai dan Kilmaskossu (1995) wilayah untuk berburu diatur oleh hak tradisional biasanya milik klen, suku atau seluruh masyarakat dan disepakati dan diterima secara tradisional di Papua. Namun demikian, perburuan dapat dilakukan di daerah yang bukan

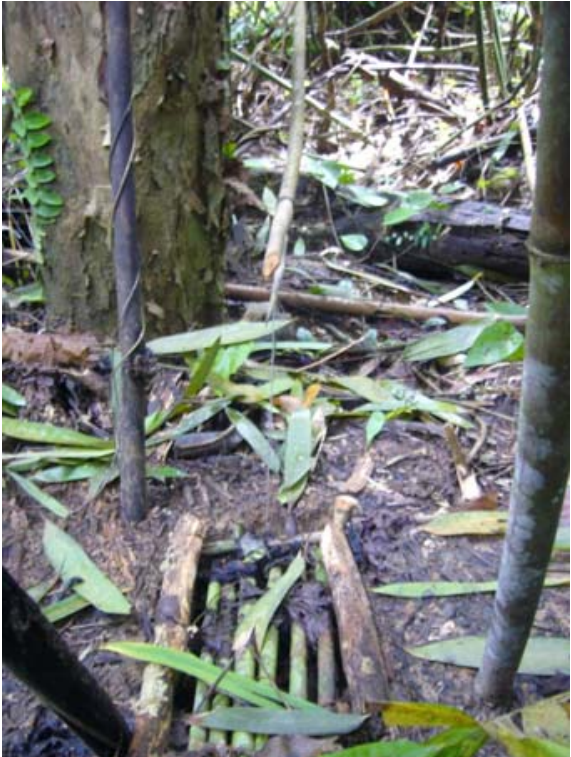

Gambar 2. Perburuan pasif menggunakan jerat.

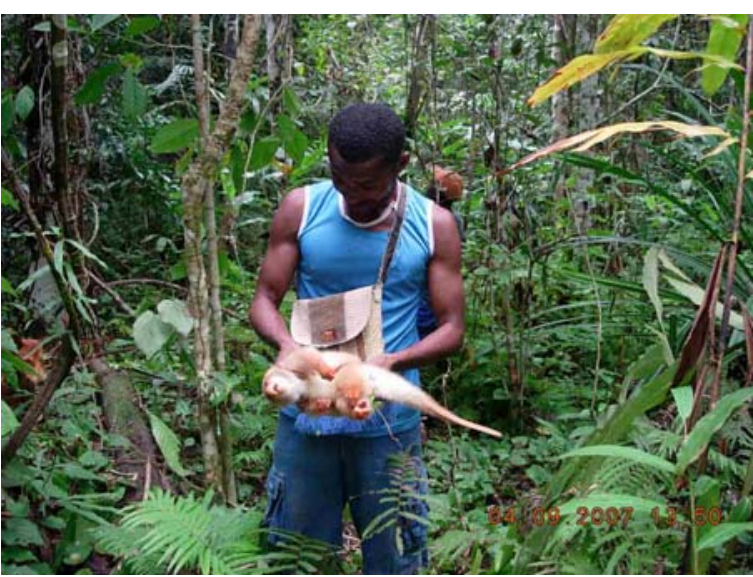

Gambar 4. Pemburu di Pulau Arui dengan kuskus hasil buruan.

merupakan hak ulayat kelompok pemburu, selama pemilik hak ulayat memberikan ijin atau dengan cara membagi hasil buruan yang diperoleh dengan kelompok pemilik ulayat. Praktek seperti ini ditemukan dalam kehidupan suku Arfak di Manokwari (Sumule, 1995).

\section{MUSIM BERBURU}

Hampir di sebagian besar lokasi penelitian masyarakat mengakui adanya musim berburu. Masyarakat Napan di kawasan Teluk Cenderawasih melakukan praktek memungut hasil baik dari laut maupun hutan secara musiman yang dikenal dengan istilah "sasi".

Musim memungut hasil biasanya diawali dengan upacara tradisional setempat dan selama musim tersebut semua penduduk desa diperkenankan untuk memungut hasil (ikan, hasil pertanian/hutan dan perburuan). Lama waktu 
musim tersebut diatur bersama oleh masyarakat setempat dan berbeda-beda di setiap kelompok etnik. Asumsi masyarakat setempat diberlakukannya musim ini sekaligus memberikan kesempatan kepada hewan buruan untuk bisa berkembang biak secara alami.

Dalam kaitannya dengan perburuan maka aktivitas perburuan tidak diperkenankan selama masa tutup sasi. Dengan demikian praktek semacam ini dianggap sebagai konsep kearifan tradisional yang mendukung usaha konservasi satwa di Papua yang masih terus berlanjut dipraktekkan di Papua.

Dalam kondisi tertentu (kegiatan yang berkaitan dengan upacara keagamaan atau ritual budaya), semua pria di dalam komunitas tertentu terlibat dalam aktivitas perburuan. Pada saat seperti ini aktivitas berburu dilakukan dalam jangka waktu yang relatif lebih lama dan biasanya dianggap sebagai musim berburu karena tujuan perburuan yaitu untuk mendapatkan hasil yang buruan yang banyak.

Hal seperti ini masih ditemukan pada kelompok etnik Kebar dan Dasigo di dataran tinggi Manokwari dan Mamberamo. Aktivitas perburuan secara bersama (komunal) biasanya dilakukan dalam perayaan ritual keagamaan dan budaya seperti perkawinan dan kematian. Dalam situasi seperti ini mereka harus mempersiapkan jamuan untuk tamu yang datang dalam jumlah besar untuk menghadiri upacara tersebut.

Pada beberapa kelompok suku di Papua New Guinea, pelaksanaan musim berburu juga berlaku dalam kaitannya dengan aktivitas pertanian masyarakat setempat misalnya setelah musim panen, musim menanam dan musim paceklik (Sillitoe, 2002). Ntiamoa-Baidu (1997) menjelaskan bahwa praktek yang sama ditemukan hampir di sebagian besar wilayah Afrika.

\section{TARGET BURUAN}

Hewan buruan di setiap daerah beragam, tetapi umumnya di Papua hewan yang menjadi sasaran perburuan relatif sama. Beberapa spesies satwa yang sering menjadi sasaran perburuan di antaranya adalah kelompok mamalia darat dan burung seperti babi hutan, rusa, walabi, kuskus, bandikut, kasuari, mambruk serta buaya dan penyu yang diburu oleh mereka yang tinggal di sekitar lahan basah.

Perburuan rusa dan babi liar misalnya hampir ditemukan di seluruh wilayah di Papua, misalnya perburuan rusa oleh masyarakat di sepanjang pesisir semenanjung Kepala Burung Papua (Gambar 3). Sementara kelompok masyarakat Mamberamo dikenal karena kemampuan mereka berburu buaya dari sungai Mamberamo.
Berburu kuskus merupakan yang umum ditemukan hampir di berbagai daerah di Papua. Di Teluk Cenderawasih, berburu kuskus memberikan kontribusi yang signifikan terhadap konsumsi protein hewani masyarakat Napan (Gambar 4).

Hal penting yang perlu dicatat yaitu pilihan terhadap satwa buruan sangat bergantung kepada kehadiran jenis satwa tersebut dan tingkat kesulitan untuk menangkapnya dan keterkaitan budaya setempat dengan satwa tersebut. Hal ini cukup beralasan karena tujuan utama perburuan yaitu untuk menyediakan sumber protein hewani utama bagi keluarga. Sebagai sumber pangan, jenis satwa tertentu memainkan peranan yang sangat penting bagi mereka di daerah pedalaman Papua.

Keterbatasan akses terhadap sumber protein hewani asal ternak dan ketersediaan pangan asal hewan liar merupakan alasan utama memanfaatkan satwa untuk dikonsumsi (Pattiselanno, 2003; Pattiselanno, 2004; Pattiselanno, 2006). Nilai komersial atau ekonomi satwa menjadi salah satu faktor penentu (penjualan daging buruan dan hewan hidup sebagai hewan peliharaan) dalam menetapkan satwa buruan sasaran di antara beberapa kelompok etnik (Noviarto, 2000; Pattiselanno, 2004; Hilaluddin dkk., 2005; Luskin dkk., 2014). Dari sisi sosial budaya hiasan tropi (kepala rusa jantan) atau taring babi, dan cakar jenis mamalia tertentu digunakan sebagai artifak budaya yang bernilai dalam ritual budaya setempat atau koleksi pribadi misalnya kulit, bulu dan taring (Kwapena, 1984, McKinnon, 1984; Beehler, 1985; Petocz, 1994, Wibowo dan Suyatno, 1998). Upacara morga di dataran tinggi Papua New Guinea membutuhkan daging babi dan kasuari dalam jumlah yang besar untuk tukar menukar budaya dan persahabatan di antara kelompok etnik (Kwapena, 1984). Selain itu juga pemanfaatan hewan liar (mamalia, burung dan reptil), termasuk daging, kulit, bulu, ekor, tulang, taring dan lemak secara luas digunakan untuk mengobati penyakit (ethnoveterinary) (Ntiamoa-Baidu, 1997).

Beberapa pustaka menjelaskan bahwa perburuan satwa dilakukan untuk mendapatkan asesori (McKinnon, 1984; Beehler, 1985; Petocz, 1994, Wibowo dan Suyatno, 1998) pada kostum tradisional. Contoh hal ini adalah bulu burung Cenderawasih dan burung Mambruk memainkan peranan yang sangat penting dalam ritual budaya kelompok suku tertentu.

\section{KEARIFAN LOKAL SEBAGAI POTENSI}

Dari pengamatan secara langsung dan hasil wawancara terhadap responden nyata bahwa perkembangan dan pembangunan yang sangat pesat 
akhir-akhir ini membuka peluang peningkatan interaksi antara masyarakat setempat dengan kelompok pendatang dari luar. Kondisi ini wajar karena pembukaan dan pemekaran sejumlah daerah baru memicu pembukaan jaringan jalan yang semakin intensif guna menghubungkan satu daerah dengan daerah lainnya. Pada akhirnya hal ini akan membuka kesempatan interaksi yang lebih besar antara masyarakat asli Papua dengan kelompok pendatang, tetapi juga memberikan kesempatan terjadinya transfer budaya diantara kelompok masyarakat ini.

Ada kekuatiran bahwa kondisi yang ada akan cenderung mengikis praktek kearifan tradisional yang selama ini secara tidak langsung merupakan aplikasi dari program konservasi tradisional masyarakat di Papua. Keterisolasian yang terbuka juga mempercepat pembangunan ekonomi masyarakat dan pada akhirnya berakibat terhadap pemanfaatan sumberdaya yang semakin intensif dan menjadi tidak terkendali.

Kesimpulan dari berbagai studi yang pernah dilakukan di berbagai tempat di dunia menunjukkan bahwa perburuan satwa tidak lagi lestari dan fenomena ini disebut dengan the empty forest (Redford, 1992). Hal mendasar yang menjadi alasan yaitu semakin meningkatnya perdagangan satwa komersial (Bodmer dkk., 1990; Fa dkk., 1995), beralihnya teknik perburuan tradisional ke perburuan modern yang cenderung menggunakan peralatan modern (Stearman, 2000; Madhusudan dan Karanth, 2002; Pattiselanno, 2006; Aiyadurai dkk., 2010) serta tidak berlakunya aturan, kepercayaan serta tabu yang umumnya dikenal oleh masyarakat tradisional yang berkaitan dengan perburuan satwa (Redford dan Robinson, 1987; Madhusudan dan Karanth, 2002).

Pada suku Maybrat khususnya kelompok masyarakat Ayfat misalnya, proses perdagangan satwa juga sekaligus menjadi ajang tukar menukar barang berharga lainnya. Contoh hal ini adalah gelang-gelang dari kulit siput, gigi taring buaya dan babi (yang tumbuh melengkung), bahan-bahan, kalung kalung dan ikat pinggang yang dihiasi dengan manik-manik dari jenis yang istimewa diantara klen yang ada (Pattiselanno dan Mentansan, 2010).

Pengalaman di beberapa tempat lain menunjukkan bahwa terbukanya keterisolasian meningkatkan interaksi suku asli dengan kelompok pendatang. Interaksi tersebut berdampak terhadap terkikisnya budaya asli seperti praktek tabu atau aturan-aturan adat yang dikenal dikenal oleh masyarakat tradisional yang berkaitan dengan perburuan satwa (Redford and Robinson, 1987;
Robinson dan Bennett, 2000; Madhusudan and Karanth, 2002).

Pada era otonomi khusus ini, salah satu bentuk keberpihakan kepada masyarakat asli Papua yaitu dilindunginya praktek kearifan tradisional oleh masyarakat. Sebagai bagian yang tidak terpisahkan dengan kehidupan sosial budaya masyarakat setempat, nilai kearifan tradisional Papua perlu dijaga, dilestarikan. Lebih penting lagi, kearifan tradisional Papua harus dimanfaatkan sebagai kekayaan budaya yang erat kaitannya dengan kekayaan keanekaragaman budaya lokal yang dimiliki bangsa ini (mega-cultural diversity).

Keputusan Majelis Rakyat Papua (MRP) mendukung kebijakan pemberdayaan di bidang sosial budaya melalui upaya menumbuh kembangkan nilai-nilai kearifan lokal masyarakat asli Papua (Anonim, 2009). Hal ini merupakan salah satu bentuk legitimasi hukum adat masyarakat di Tanah Papua guna melestarikan praktek kearifan tradisional yang selama ini lebih terkotak-kotak menurut kelompok etnik yang ada. Kearifan tradisional/lokal (traditional wisdom) adalah sistem sosial, politik, budaya, ekonomi dan lingkungan dalam lingkup komunitas lokal. Sifatnya dinamis, berkelanjutan dan dapat diterima. Dengan demikian kearifan lokal yang lahir dari learning by experience, tetap dipertahankan dan diturunkan dari generasi ke generasi (Pattinama, 2009), merupakan sikap positif yang perlu tetap dipertahankan dalam kehidupan Papua modern saat ini.

Hasil yang diperoleh menunjukkan bahwa kegunaan utama kearifan lokal adalah untuk menciptakan keteraturan dan keseimbangan antara kehidupan sosial, budaya dan kelestarian sumberdaya alam. Dalam penerapannya, kearifan tradisional/lokal bisa dalam bentuk hukum, pengetahuan, keahlian, nilai dan sistem sosial dan etika yang hidup dan berkembang dari satu generasi ke generasi berikutnya. Sebagai bentuk interaksi antara manusia dan satwa liar, pemanfaatan satwa oleh manusia merupakan bagian dari siklus alami yang ikut mengatur kondisi populasi satwa di alam. Dalam konteks aktivitas perburuan hubungan ini juga menggambarkan praktek etika konservasi yang dianut masyarakat setempat sebagai bagian dari pemanfaatan sumberdaya alam yang ada (Pattiselanno, 2008).

Oleh karena itu kearifan tradisional yang merupakan produk lokal masyarakat perlu tetap dipertahankan bahkan harus lebih ditingkatkan. Potensi ini perlu secara lebih intensif digali dan terus ditingkatkan karena hasil kajian yang dilakukan di tempat lain di belahan dunia lainnya menunjukkan bahwa konservasi satwa dapat dilakukan melalui pendekatan aspek kearifan lokal 
dan pengetahuan lokal (indigenous knowledge) masyarakat setempat. Pemanfaatan potensi ini diharapkan menjadi salah satu solusi di tingkat masyarakat adat guna mendukung usaha perlindungan satwa di Papua.

\section{KESIMPULAN}

Aspek kearifan tradisional masyarakat asli Papua beragam antara satu kelompok etnik dengan kelompok etnik lainnya. Berdasarkan aspek yang dikaji konsep kearifan tradisional yang selama ini dipraktekkan secara turun temurun dalam aktivitas perburuan nampak pada teknik dan pengunaan alat berburu, lokasi berburu, musim berburu dan satwa yang menjadi target perburuan. Dalam kenyataannya, praktek kearifan tradisional di Papua secara tidak langsung ikut menunjang program konservasi satwa. Konsep tersebut merupakan potensi yang perlu dilestarikan sejalan dengan Keputusan Majelis Rakyat Papua mendukung dan mengembangkan nilai kearifan lokal masayarakat asli Papua. Potensi ini merupakan bagian dari kekayaan keanekaragaman budaya lokal (megacultural diversity) yang dimiliki masyarakat dalam menunjang program konservasi flora fauna di Tanah Papua.

\section{DAFTAR PUSTAKA}

Aiyadurai, A., Singh, N.J., dan Milner-Gulland, E.J., 2010. Wildlife hunting by Indigenous Tribe: A Case Study from Arunacahal Pradesh, North-east India. Oryx, 44(4):564-572.

Anonim, 2009. Keputusan Kultural Majelis Rakyat Papua tentang: Kebijakan dan Pembinaan Kesatuan Kultural Orang Asli Papua. Sekretariat Majelis Rakyat Papua, Jayapura.

Beehler, B., 1985. Conservation of New Guinea Rainforest Birds. ICBP Technique Publication, 4:233-247.

Bennet, E.L. dan Robinson, J.G., 2000. Hunting of Wildlife in Tropical Forest: Implications for Biodiversity and Forest Peoples. Paper No. 76 on Biodiversity series - impact studies. World Bank and WCS, Washington DC.

Bodmer, R.E., Bendayan, A.N.Y., Moya, I.L., dan Fang, T.G., 1990. Manejo de ungulados en la Amazonia Peruana: Analisis de su Caza y Commercializacion. Boletin de Lima, 70:4956.

Chahya, D.N., 2000. Teknologi Berburu Rusa (Cervus timorensis) dan Kasuari (Casuarius, sp.) Secara Tradisional Pada Masyarakat Suku Marind dan Kanuum di dalam kawasan
Taman Nasional Wasur Merauke. Skripsi Universitas Negeri Papua, Manokwari.

Fa, J.E., Garcia Yuste, J.E., dan Castelo, D., 2000. Bushmeat markets on Bioko Island as measure of hunting pressure. Conservation Biology, 14(6):1602-1613.

Flannery, T., 1995. Irian Jaya's New Tree Kangaroo: Just The Tip of The Ertzberg. Nature Australia Winter: 47-52.

Hilaluddin, Kaul, R., dan Ghose, D., 2005. Conservation Implications of Wild Animal Biomass Extractions in Northeast India. Animal Biodiversity and Conservation, 28(2):169-179.

Hill, K., dan Padwe, J., 2000. Sustainability of Ache Hunting in the Mbaracayu Reserve, Paraguay, dalam. J.G. Robinson dan E.L. Bennett, (eds.). Hunting for Sustainability in Tropical Forests. Columbia University Press, New York: 79-105

Kwapena, N., 1984. Traditional Conservation and Utilization of Wildlife in Papua New Guinea, The Environmentalist, 4(7):22-26

Lee, R.J., 2000. Impact of Subsistence Hunting in North Sulawesi, Indonesia and Conservation Options, dalam J.G. Robinson and E.L. Bennett, (eds.). Hunting for Sustainability in Tropical Forests, Columbia University Press, New York: pp. 455-472

Leuwenberg, F.T., dan Robinson, J.G., 2000. Traditional Management of Hunting in a Xavante Community in Central Brazil: the Search of Sustainability, dalam J.G. Robinson dan E.L. Bennett, (eds.). Hunting for Sustainability in Tropical Forests, Columbia University Press, New York: pp. 375-394.

Luskin M.S., Christina, E.D., Kelley, L.C., dan Potts, M.D., 2014. Modern Hunting Practices and Wild meat Trade in the Oil plantationdominated Landscape of Sumatra. Human Ecology, 42:35-45.

Mc Kinnon, K., 1984. Alam Asli Indonesia Flora, Fauna dan Keserasian. PT. Gramedia Jakarta

Madhusudan, M.D., dan Karanth, K.U. 2002. Local Hunting and The Conservation of Large Mammals in India. Ambio, 3(1):49-54.

Manembu, N.A., 1991. Suku Sempan, Nakai, Nduga dan Amungme di Kawasan Lorentz. PHPA/WWF Project 4521. Jayapura.

Milner-Gulland, E.J., dan Bennett, E 2003. Wild meat: The Bigger Picture. TRENDS in Ecology and Evolution, 18(7):351-357.

Noviarto, R.D., 2000. Tingkat Konsumsi dan Pemasaran Daging Walabi lincah (Macropus agilis) oleh Penduduk Asli dalam Taman Nasional Wasur Merauke. Skripsi Universitas Negeri Papua, Manokwari. 
Ntiamoa-Baidu, Y., 1997. Wildlife and Food Security in Africa. FAO Conservation Guide 33 www.fao.org/docrep/W7540E.

Paijman, K., 1976. New Guinea Vegetation. The Australian National University Press, Canberra.

Pattinama, M.J., 2009. Pengentasan Kemiskinan dengan Kearifan Lokal (Studi Kasus di Pulau Buru-Maluku dan Surade-Jawa Barat). Makara, Sosial Humaniora, 13(1):1-12.

Pattiselanno, F., 2003. The wildlife value: example from West Papua, Indonesia. Tigerpaper, 30(1):27-29.

Pattiselanno, F., 2004. Wildlife utilization and food security in West Papua, Indonesia. The SEARCA Agriculture and Development Seminar Series, SEARCA Los Baños, The Philippines 13 April 2004.

Pattiselanno, F., 2005. Traditional Hunting for Sustainable Wildlife Management (Current Review on Wildlife Hunting in West Papua). Proceeding of the 7th of New Guinea Biological Conference, Universitas Cenderawasih Jayapura, June 16-18, 2005.

Pattiselanno, F., 2006. The Wildlife Hunting in Papua. Biota, 11(1):59-61.

Pattiselanno, F., 2008. Man-wildlife Interaction: Understanding the Concept of Conservation Ethics in Papua. Tigerpaper, 35(4):10-12.

Pattiselanno, F., dan Mentansan, G., 2010. Kearifan Tradisional Suku Maybrat dalam Perburuan Satwa sebagai Penunjang Pelestarian Satwa. Makara Sosial Humaniora, 14(2):75-82.

Petocz, R.G., 1994. Konservasi Alam dan Pembangunan Irian Jaya. Graffitti Press, Jakarta.
Redford, K.H., 1992. The Empty Forest. Bioscience 42:412-422.

Redford, K.H., dan Robinson, J.G., 1987. The Game of Choice: Patterns of Indian and Colonist Hunting in the Neotropics. American Anthropologist, 89:412-422.

Robinson, J.G., dan Bennett, E.L., 2000. Hunting for sustainability in Tropical Forests. Columbia University Press, New York.

Sillitoe, P., 2002. Always been Farmer-foragers? Hunting and Gathering in the Papua New Guinea Highlands. Anthropological Forum, 12(1):45-76.

Sumule, A.I., 1995. The Technology Adoption Behaviour of the Indigenous People of Irian Jaya: A Case Study. Fakultas Pertanian, Universitas Cenderawasih, Manokwari.

Stearman, M.A., 2000. Pound of Flesh: Social Change and Modernization as Factor in Hunting Sustainability among Neotropical Indigenous Societies, dalam J.G. Robinson dan E.L. Bennett, (eds.). Hunting for Sustainability in Tropical Forests, Columbia University Press, New York: 233-250.

Wanggai, F., dan Kilmaskossu, M.St.E., 1995. Partisipasi Masyarakat dalam Kegiatan Konservasi Taman Nasional Laut Teluk Cenderawasih. Rapat Koordinasi Pembangunan Taman Nasional Laut Teluk Cenderawasih. Manokwari, 30 September 1999.

Wibowo P., dan Suyatno, N., 1998. An Overview of Indonesian Wetland Sites II. Directorate General of Forest Protection and Nature Conservation and Wetlands International Indonesia Programme, Jakarta. 